\title{
Gender Equality and the Supreme Court: Taking Another Look
}

\author{
Joseph Ignagni and Thomas R. Marshall, University of Texas at Arlington
}

A review of 107 gender equality claims reaching the Supreme Court since Reed $v$. Reed (1971) indicates that the Court's treatment of abortion rights claims differed greatly from nonabortion claims. The Court's changing makeup was strongly related to its support for abortion rights, but not to its support for nonabortion gender equality claims. Litigants and legal facts strongly affected the Court's support for nonabortion gender equality claims, but not abortion claims. Public opinion indicators were either unrelated (to nonabortion gender equality claims) or showed an unexpected, negative linkage (to abortion rights claims).

Since its landmark Reed $v$. Reed (1971) ruling, the United States Supreme Court adopted a more exacting standard in reviewing laws and policies that treated men and women differently. To be sure, the Supreme Court has not yet held gender-based distinctions to its most demanding standard (the "strict scrutiny" test), which would strike down virtually all legal distinctions between men and women. Indeed, the Court's rulings have often been described as piecemeal, and made on an issue by issue basis. In 1976, however, the Supreme Court created what is often called the "intermediate level" of judicial scrutiny. The Court has used that standard to strike down many laws and policies that distinguish between men and women, although it has still allowed some gender-based distinctions. ${ }^{1}$

The Supreme Court did not confine itself solely to reviewing gender equality claims against laws and policies that treated men and women differently. Roe v. Wade (1973) and Doe v. Bolton (1973) initiated a second group of rulings addressing the availability of abortion, further expanding the notions of gender equality. The importance of these abortion and nonabortion rulings, taken together, sparked a vast literature exploring the legal issues raised in these cases, and the impact of these rulings on American society. These papers, articles, and books have pointed to a variety of explanations as to why the Supreme Court has supported some gender equality claims, but not others. Some of these theories, reviewed at greater length below, focus on political explanations, especially the Court's changing composition, while others focus on case-specific explanations. ${ }^{2}$

JOSEPH IgNAGNI is Associate Professor of Political Science at the University of Texas at Arlington. ThOMAS R. MARSHALl is Professor of Political Science at the University of Texas at Arlington.

The American Review of Politics, Vol. 16, Fall, 1995: 239-252

${ }^{\odot} 1995$ The American Review of Politics 
To date, scholars have not used statistical techniques to directly compare the strength of some explanations versus others. This article reexamines the Supreme Court's gender equality rulings from 1971 through the 1993 term, testing several theories to explain why the Supreme Court has supported some gender equality claims, but not others.

\section{Methodology}

No single, up-to-date listing is available of all the Supreme Court's abortion and nonabortion gender equality rulings since 1971 . To define the Court's gender equality rulings, major casebooks, articles, and the Spaeth data base were reviewed for cases involving an issue that tapped either abortion availability or the differential treatment of men and women. Only full opinion cases were included. For the most recent Supreme Court terms, all full opinion cases were reviewed for these issues, through the end of the 1993 Court term.

A total of 107 gender equality claims received a full Court opinion during the 1971-1993 Court terms-an average of 4.4 claims per term. These 107 claims raised a wide variety of claims, including on-the-job workplace claims, abortion claims, criminal rights claims, pension rights claims, students' claims, and military service claims, among others. As noted elsewhere (Baer 1991), gender equality claims do not include only claims raised by women; a substantial number (23) of claims were raised by males. $^{3}$

In most instances, the decisions analysed here included only a single claim. A few cases, however, involved multiple claims, which were counted and coded separately. For example, Webster v. Reproductive Health Services (1989) was counted as involving two different claims, first, fetal viability, and second, the public hospital ban on nontherapeutic abortions. ${ }^{4}$

For each claim that received a full Court opinion, the Supreme Court could have supported the abortion or nonabortion gender equality claim (coded as 1), or rejected it (coded 0 ). Overall, the Court supported roughly three of every five such claims raised-supporting 63 claims $(59 \%)$ and rejecting 44 claims $(41 \%)$. More specifically, the Court supported 53 percent of the 40 abortion rights claims, and 63 percent of 67 nonabortion gender rights claims.

\section{Supreme Court Support for Gender Equality Claims}

How best can one explain when the United States Supreme Court will support an abortion or nonabortion gender equality claim? The available 
literature, reviewed below, offers four explanations from which several testable hypotheses can be derived. Each of these four explanations is outlined below, then tested.

\section{The Supreme Court's Composition}

The first explanation is that the Supreme Court's support for gender equality is related to the Supreme Court's own composition. In particular, the election of a series of Republican presidents during the 1970s and 1980s led to the appointment of a steadily growing number of conservative Republican justices, compared to earlier decades. This argument is widely cited for abortion rights claims (Savage 1992). As well, during this period the Court's first (then second) woman justice joined the brethren.

Several variables are available for testing. The first two variables (both ratio-level) measure either the number of Republican justices on the Court, or alternatively, the number of Reagan-Bush appointees (all of whom were Republicans). For both predictors, the hypothesis is that the greater the number of Republicans (or Reagan-Bush Republicans), the lower the support for either abortion or nonabortion gender equality claims. Because the Reagan-Bush appointees were "abortion-cleared" (or at least "abortionscrutinized"), the hypothesis is made more strongly for the Reagan-Bush appointees and for abortion claims (Savage 1992; Epstein and Kobylka 1992; Stidman, Carp, and Rowland 1983).

A third predictor is the number of women members on the Supreme Court, ranging from 0 (until 1981) to 1 to 2 (only for the 1993) term. Several accounts have debated whether women justices are especially sensitive to gender rights claims, or whether a woman justice's presence influences other justices' votes, as well ( O'Connor and Epstein 1983; O'Connor and Segal 1990; Savage 1992; Miller 1985; Gryski, Main, and Dixon 1986; Sherry 1986). The hypothesis is that the greater the number of women on the Court, the greater the Court's support for gender rights claims will beat least when controlling for the Supreme Court's changing composition over time. Because Sandra Day O'Connor was the only woman justice from 1981 until the 1993 term, this variable is also tested as a simple $(0,1)$ dummy variable to test the presence or absence of Justice O'Connor.

\section{American Public Opinion}

A second explanation is that the Supreme Court responds either directly or indirectly to prevailing American public opinion. The Court might follow American public opinion directly if justices "sense and share" public senti- 
ment on specific issues (Rehnquist 1987); alternatively, the justices might follow less direct indicators of public opinion, such as recent election returns or social trends (Marshall 1989; Mishler and Sheehan 1993). Nine indicators were used to tap public opinion on gender rights claims.

The first indicator is the prevailing national public opinion "mood." The national mood refers to cycles in American public opinion. Two separate studies have suggested that American public opinion became more liberal, then more conservative, then more liberal again from the mid-1950s to the early 1990s (Stimson 1992; Smith 1990). Here, Stimson's (1989) ratio-level variable was used to measure the national mood. ${ }^{5}$ The prediction is that the Court's rulings on gender equality claims will reflect the current national mood.

A second prediction is that the Court will follow the national mood, but lag behind the current mood by several years (Mishler and Sheehan 1993). In this version, as reported in Table 1, the justices are predicted to reflect prevailing attitudes, but with a time lag of three years. ${ }^{6}$

Both these indicators may be too general to capture American public opinion toward gender equality, per se. A third and fourth (ratio-level) public opinion variables were constructed from National Opinion Research Center (NORC) trend items since 1972. One of these trends taps poll items reflecting attitudes toward abortion related items, while the other trend taps NORC poll items toward women's roles (excluding abortion). The prediction is that Court support for abortion availability will reflect public attitudes toward abortion issues, and that Court support for nonabortion issues will reflect the trend of nonabortion poll items tapping women's roles. ${ }^{7}$

A fifth indicator is that the Supreme Court will reflect American public opinion on the specific dispute involved in a case. Testing this indicator is more problematic, because it requires a specific poll item to match a specific claim raised in a Supreme Court case. For 20 of these 107 claims, a specific, scientific nationwide poll item could be identified. For this subsample of 20 claims, this hypothesis could be directly tested. For this indicator, the Court's support for a gender rights claim is predicted to be positively related to the percentage of Americans who support the specific claim in a nationwide poll. ${ }^{8}$

American public opinion may influence the Supreme Court in less direct ways, if the Court follows recent presidential or congressional election returns. To test this possibility, four other indicators were also tested. A sixth prediction is that the Court's acceptance of gender rights claims will rise when Democrats win more seats in the U.S. House of Representatives. The seventh and eighth predictions hold that the Supreme Court will more often support gender rights claims when the Democratic candidate for Presi- 
dent wins a larger share of the total popular vote, or alternatively, a larger share of the two-party vote. ${ }^{9}$ The ninth prediction is that the Court's support for gender rights claims will reflect the growing number of women elected to the U.S. House of Representatives.

\section{Litigants Involved}

A third explanation is that the Supreme Court's rulings in gender equality and abortion rights claims might be influenced by the litigants involved. Several accounts have argued that the U.S. Solicitor General strongly influences the Supreme Court's decision-making, and may be the most (arguably, the only) significant influence on Supreme Court decision-making apart from the justices' own ideological views (Caplan 1987; Segal 1984; Segal and Spaeth 1993). This predictor measures the Solicitor General's position on a gender rights claim, coded as $(+1)$ for supporting the claim, $(0)$ if not participating in the case, and (-1) if opposing a claim. The prediction is that the Solicitor General's support is more strongly related to Supreme Court support for gender and abortion rights claims than is any other predictor (Segal and Spaeth 1993).

A second indicator here is whether a federal law or policy is involved. Typically, the Supreme Court is much more deferential toward federal-level, than to state- or local-level laws and policies (Abraham 1987, 67). Federal laws and policies supportive of the gender rights claim are coded as $(+1)$; federal laws or policies which oppose the claim are coded as $(-1)$; otherwise (0). The prediction is that gender rights claims will fare better when the federal law or policy supports the claim. ${ }^{10}$

A third indicator is whether a state- or local-level law or policy is involved in the gender rights claim. The prediction is that the Court will be less influenced by state- or local laws than by federal laws. This variable is coded similarly to the federal level variable just described.

A fourth indicator is region. Some evidence suggests that Southern states fare less well than nonSouthern states when their laws and policies are challenged at the Supreme Court (Hagle 1992; Epstein and O'Connor 1988). The prediction is that the Court will more often support a gender equality claim arising from a Southern state than from another part of the nation. Cases from the South are coded as 1 , otherwise 0.

The Supreme Court may also possibly respond to the number or type of interest groups filing an amicus brief in the lawsuit. Here, three further indicators were tested: the number of interest groups filing an amicus brief in favor of the rights claim, the number filing an amicus against the rights claims, and the total number of groups filing amicus briefs. The number and 
types of interest groups involved may cue the Court to the importance of the claim involved. Because past research has not shown that amicus brief filings significantly impact the Court's rulings at the full decision stage, all these variables are predicted to be unrelated to the Court's rulings (Epstein and Rowland 1991; Caldeira and Wright 1988).

\section{Facts and Circumstances}

The fourth explanation of the Supreme Court's support for abortion rights or gender equality rights focuses on legal facts involved in the case. Several published accounts have suggested that legal facts "matter" in Supreme Court decision-making (Segal 1984; George and Epstein 1992). A wide variety of facts and circumstances appeared in these 107 full Court decisions. A review of legal research, however, suggested that some might favorably influence the Court's acceptance of a gender rights claim, while others might have the opposite effect.

Case facts predicted to have a positive effect on a gender equality claim include: an on-the-job workplace claim, a pension rights claim, a workplace pregnancy claim, or a jury composition claim. By contrast, several other facts were predicted to be negatively related to the Supreme Court's acceptance of a gender rights claim, including: a claim made by a criminal defendant, a claim for retroactive application, a claim asserted by a minor or by a student, an intra-family custody claim, a claim asserted by a male, a claim which would force a unit of government to finance a new activity, or a claim involving military service. More generally, the Court is also predicted to treat abortion claims less favorably than workplace claims (Goldstein 1988; Epstein and Kobylka 1992).

Because many of these specific facts or circumstances appear in only a handful of the 107 claims examined here, a composite (index) score was constructed for the legal fact variables (Segal 1984). The appearance of a legal fact hypothesized to be negatively related to a legal claim was scored as a $(-1)$, while a legal fact hypothesized to be positively related to the Court's decision was scored as a (+1). Many of the legal fact variables only apply in the nonabortion cases. The resulting index provided a score, per claim, ranging from $\mathrm{a}-2$ to $\mathrm{a}+3$.

\section{Data Results and Discussion}

Because the number of cases is relatively small compared to the large number of predictors, and because many variables are strongly intercorrelated, the variables were first tested individually against the dependent 
variable-whether the Supreme Court supported or opposed the gender equality claim (coded as 1,0 , respectively). Since the dependent variable is dichotomous, the predictors were tested in probit equations. Table 1 reports the strength and significance of the predictors, tested one-by-one.

Table 1 presents probit results for each predictor individually. Figures reported in Table 1 indicate the maximum likehihood estimate divided by its standard error (M.L.E./S.E.) with the accompanying statistical significance level. The first column reports results for all 107 claims. The second column reports results only for the 40 abortion-related claims, while the third column reports results for the 67 non-abortion claims.

The results in Table 1 suggest that gender equality claims and abortion rights claims over the last two decades reflect very different legal patterns. Combined, all 107 claims are not well predicted by the variables, and only a few variables help to explain the Supreme Court's pattern of decisionmaking. ${ }^{11}$ Support for claims was significantly related to the Solicitor General's position and to legal facts; abortion claims also received less support than nonabortion claims. The Democratic candidate's share of vote for president, however, was significantly, but negatively related to Court support for gender equality claims. This unexpected finding can be explained by the dwindling (but still winning) vote margins of Republican presidents who continued to appoint conservative and Republican justices to the Court (Mishler and Sheehan 1993).

When separately analysed, the different patterns of decision-making for abortion versus nonabortion claims become readily apparent. For abortion claims, the growing number of Republican (or Reagan-Bush Republican) justices is especially important. Ironically, the strength of Democratic presidential candidates and public opinion poll support for women's role in the workplace is also significantly, albeit negatively related to the Court's acceptance of abortion claims. None of the litigants or judicial facts tested could significantly predict the outcome of abortion claims.

For the nonabortion gender equality claims, a very different structure of decision-making is apparent. Neither the Court composition variables nor the public opinion variables significantly predicted Supreme Court support for nonabortion gender equality claims. Instead the Court's decisions were more closely linked to the the Solicitor General's position and to the number of pro-claim amicus briefs, as well as to legal facts in the claims.

How well can these variables explain abortion and nonabortion gender equality claims? A variety of probit models were tested, combining predictors into a multivariate model. On grounds of parsimony, predictive success, or theoretical clarity, a few probit models stood out and are reported in Tables $2 \mathrm{a}, 2 \mathrm{~b}$, and 3 . 
Table 1. Supreme Court Support for Gender Rights Claims

(Table Entries indicate M.L.E./S.E. and Significance Levels)

Predictor

Number GOP Justices

All

Abortion

Nonabortion

Number Reagan-Bush Justices

Cases

Cases

Cases

Justice O'Connor

Number Women Justices

$\begin{array}{rcc}-1.06 & -1.99 * & .46 \\ -.59 & -1.67 * & .77 \\ .01 & -.39 & .70 \\ -.06 & -.39 & .08\end{array}$

\section{American Public Opinion}

National Mood

$-.50$

$-1.34$

.67

Lagged National Mood

$-.37$

$-1.08$

$-1.17$

$-2.33 * *$

.54

Mood Women in Workplace

Mood toward Abortion

.62

.43

.84

Support for Specific Claim

Number Democrats in U.S. House

.58

$-.58$

.66

$-.34$

$-.22$

.32

Dem. Share Total Pres. Vote

$-1.70 *$

$-2.99 * *$

$-.24$

$-1.79 *$

$-2.88 * *$

.06

Dem. Share Two-Party Pres. Vote

Number Women in U.S. House

$-.61$

$-1.17$

$-.09$

LITIGANTS INVOLVED

Solicitor General

$1.65^{*}$

.26

.52

Federal Law or Policy

State/Local Law or Policy

South

1.53

.23

$1.71 *$

.63

$-1.14$

1.16

.05

$-.60$

.71

.04

$-.90$

.11

Number Pro-claim amicus Briefs

$-1.16$

$-.75$

$1.76 *$

Number Anti-claim amicus Briefs

Number Total Amici Briefs

$-.48$

$-.86$

$-1.24$

\section{Facts and Circumstances}

Workplace Claim

1.16

$-.47$

Pension Claim

.50

Workplace Pregnancy Claim

.67

Jury Composition Claim

Student Claim

$-.37$

$-.37$

$-.88$

Retroactivity Claim

Minor Claim

$-.21$

Male Claim

$-1.21$

$-1.12$

$-1.35$

$-.53$

$1.90 *$

$-1.73 *$

NA

NA

$-.84$

NA

.27

NA

NA

$-.53$

NA

$-.53$

NA

$-1.12$

$-.16$

.14

NA

-1.80 *

$-.38$

.30

Military Claim

Family Law Claims

$-.16$

$-1.52$

NA

$-.78$

Index of Facts

Abortion Claim

$-.24$

NA

$2.17 *$

*significant at .05

**significant at .01

$\mathrm{NA}=$ insufficient covariance to permit probit analysis.

NOTE: All table entries indicate M.L.E./S.E. values for individual variables, entered one-by-one. 
Table 2a. Probit Equation for Abortion Rights Claims

\begin{tabular}{lccc}
\hline & MLE & S.E. & MLE/S.E. \\
Mood Toward Women in Workplace & -.08 & .045 & $-1.78^{*}$ \\
Dem. Share Total Pres. Vote & -.15 & .054 & $-2.76 * *$ \\
Intercept $=11.46$ & & & \\
-2 LLR $=($ significant at .05$)$ & & & \\
$\%$ of cases predicted correctly $=82 \%$ & & \\
Mean of dependent variable $=.53$ & & \\
Percentage improvement over base rate $=62 \%$ & \\
\hline
\end{tabular}

Table 2b. Alternative Probit Equation for Abortion Rights Claims

\begin{tabular}{lccc}
\hline & MLE & S.E. & MLE/S.E. \\
Number GOP Justices & -.34 & .17 & $-1.99 *$ \\
Intercept $=1.93$ & & & \\
-2 LLR $=($ significant at .05$)$ & & & \\
$\%$ of cases predicted correctly $=70 \%$ & & \\
Mean of dependent variable $=.53$ & & \\
Percentage improvement over base rate $=36 \%$ & & \\
\hline
\end{tabular}

Table 3. Probit Equation for Nonabortion Gender Equality Cases

\begin{tabular}{lccc}
\hline & MLE & S.E. & MLE/S.E. \\
Solicitor General & .24 & .15 & $1.65^{*}$ \\
Index of Facts & .20 & .12 & $1.70 *$ \\
Intercept $=.23$ & & & \\
$-2 \mathrm{LLR}=($ significant at .05$)$ & & & \\
$\%$ of cases predicted correctly $=80 \%$ & & \\
Mean of dependent variable $=.63$ & & \\
Percentage improvement over base rate $=54 \%$ & \\
\hline
\end{tabular}


For abortion claims, the strongest predictive model included the variables representing attitudes toward women in the workplace and the share of the presidential vote received by the Democratic candidate. Both predictors, however, were significantly but negatively related to Supreme Court support for abortion rights claims.

The two-predictor model reported in Table 2a successfully predicted 82 percent of the abortion rights claims, compared with a 53 percent base rate-or a 62 percent improvement over the base rate. The success of this model over this period (1971-1994), however, does not reflect a direct causal linkage, but rather the typical success of Republican presidents to win increasingly narrow election victories; once elected, these Republican presidents appointed conservative and Republican nominees to the Court who often voted against abortion rights claims. As Mishler and Sheehan (1993) have pointed out, this model illustrates the growing gap between Supreme Court decision-making and American public sentiment.

Although the two-predictor model reported in Table 2a best predicted outcomes, it is not theoretically satisfying. An alternative model for abortion claims is reported in Table $2 \mathrm{~b}$, and includes only a single predictor-the number of Republican justices. This model also significantly improves over the base rate, correctly predicting 70 percent of the abortions rights claims. While it is not so successful as the two-predictor model just described, it does reflect more clearly the impact of the appointments process on this highly politicized area of Supreme Court decision-making (Savage 1992).

For nonabortion gender equality claims, the best probit equation included only two predictors: the Solicitor General's position and the index representing the legal facts in the case. Both these variables are theoretically satisfying, and reflect the more traditional facts-and-litigants-based "legal model" of judicial decision-making (George and Epstein 1992). Both predictors were also related to Supreme Court support in the expected manner (see Table 3.) This two-predictor model successfully predicted 80 percent of the nonabortion gender equality claims, compared to a 63 percent base rate-an improvement of 54 percent over the base rate.

When all 107 claims were combined, none of several probit equation models tested could significantly improve over the base rate prediction level. ${ }^{12}$ Overall, these results suggest that the Court's many gender equality rulings-both for the abortion and nonabortion claims-were not completely ad hoc rulings without a structure. The decision-making structure of abortion rights claims, however, differed greatly from nonabortion gender equality claims, and these two lines of rulings are sufficiently different that they are better analysed separately. 
Perhaps surprisingly, American public opinion-however measureddid not demonstrate any positive linkage to Supreme Court decision-making in gender equality claims. For abortion claims, most of the public opinion coefficients in Table 1 were either statistically insignificant or significant, but negative. For nonabortion claims, none of the direct or indirect indicators of public opinion were significant at all. These results suggest that, unlike most other areas of civil liberties and civil rights claims (Ignagni and Marshall 1994), American public opinion clearly failed to influence Supreme Court decision-making on gender equality claims.

The very different decision-making structure represented by the abortion versus nonabortion claims further suggests that even within the same time period, the Supreme Court may give differing weight to legal versus extralegal variables (George and Epstein 1992). The evidence here suggests that the nonabortion gender equality claims were not "politicized" in the same way as were abortion claims, and that the growing number of Republican and conservative justices did not negatively impact these claims in the same way as in the highly publicized abortion cases. The Supreme Court's distinction between abortion and nonabortion rights claims mirrors the distinction frequently drawn in public debate over feminist issues since the early 1970s. For example, during the debate over ratifying the Equal Rights Amendment, many of the amendment's supporters argued that ratification would not affect access to abortion (Fielder 1984; Alexander and Fielder 1980; Mathew and DeHart 1990; Mansbridge 1986).

Finally, these results also suggest that the partisanship of newlyappointed Supreme Court justices may significantly impact the Supreme Court's support for abortion rights claims, but not the Court's support for nonabortion gender equality claims. A hypothetical increase from one Democratic justice to three Democratic justices on the Supreme Court, for example, markedly increases the probability of a pro-claim abortion rights ruling-from a predicted 21 percent probability to a predicted 46 percent probability. By comparison, the same change in the Supreme Court's partisan makeup has very little impact on the outcome of a nonabortion gender rights claim-changing the probability of a proclaim outcome only from 77 to 73 percent. This comparison reinforces the conclusions just discussedthat abortion and nonabortion gender rights claims show markedly different decision-making patterns.

\section{NOTES}

${ }^{1}$ Before Reed v. Reed (1971) the Supreme Court had typically applied the "rational standard" test to laws and policies which treated men and women differently. Under this 
test laws and policies might be upheld even if they were based on traditional or stereotypic gender roles and set out rigid legal distinctions between men and women without considering individual circumstances (Goldstein 1988; Rhode 1989).

${ }^{2}$ For a review of this extensive literature, see, for example, Goldstein (1988); Markowitz (1989); Ginsburg and Flagg (1989); Cole (1984); Minor (1987); Ginsburg (1988); Rubin (1986); O'Connor and Epstein (1983); Baer (1991); Kirp, Yudof, and Franks (1986); Rhode (1989); O’Connor (1980); and George and Epstein (1991).

${ }^{3}$ Examples of gender equality claims raised by males include Kahn $v$. Shevin, 416 U.S. 351 (1974); Orr v. Orr, 440 U.S. 268 (1979); or Mississippi University for Women v. Hogan, 458 U.S. 718 (1983).

${ }^{4}$ In the Webster ruling, the Court declined to pass on the constitutionality of a preamble to the state law that held life begins at conception. The Court also held moot a prohibition on the use of public funds to counsel a woman to have a nontherapeutic abortion. When the Court's majority declined to make a ruling on an issue in this manner, or when a challenged law was decided on the basis of a very similar facts in a precedent case, the claim is not counted here. In addition to Webster, seven other rulings were coded as involving two or more claims, typically involving a financial claim and a retroactivity claim, or a multi-section abortion regulation: Planned Parenthood $v$. Danforth, 428 U.S. 52 (1976); Los Angeles Department of Water and Power v. Manhart, 435 U.S. 702 (1978); Akron v. Akron Center for Reproductive Health, 462 U.S. 416 (1983); Planned Parenthood v. Ashcroft, 462 U.S. 476 (1983); Arizona Governing Committee v. Norris, 462 U.S. 1073 (1983); Thornburgh v. American College of Obstetricians and Gynecologists, 476 U.S. 747 (1986); and Planned Parenthood of Southeastern Pennsylvania v. Casey, 120 L.Ed. 2d 674 (1992).

${ }^{5}$ Published figures were updated courtesy of the author.

${ }^{6}$ This variable was also tested with lags of one, two, four, and five years, but failed to reach statistical significance.

${ }^{7}$ Poll support for women's roles increased from an (average) value of 54 in 1972 to a value of 72 in 1989 on repeat poll items. On the abortion-related items, poll support for abortion availability fluctuated from a value of 63 in 1972 to a value of 66 in 1989; see NORC codebooks for those years. Items were coded to be consistent with Stimson (1992).

${ }^{8}$ For a description of the matching of claims and nationwide polls, see Marshall (1989); for a listing of these 20 poll-to-ruling matches, contact the authors.

'The Democratic presidential candidate's share of the two-party vote excludes all votes received by minor party candidates.

${ }^{10}$ This predictor differs from the Solicitor General predictor when an agency's own attorneys defend a challenged statute, or when the Solicitor General files a position in a dispute not directly challenging a federal law or policy.

${ }^{11}$ The variables measuring the presence of Justice Sandra Day O'Connor, or the variable representing the number of women on the Court was not significantly related to overall support for gender equality claims, to abortion rights claims, or to nonabortion rights claims, either alone or when controlling for the number of Reagan-Bush appointees.

${ }^{12}$ These conclusions would not change if claims raised by a male were excluded from the analysis. 


\section{REFERENCES}

Abraham, Henry. 1987. The Judiciary. Dubuque, IA: Wm. C. Brown.

Alexander, Elizabeth, and Maureen Fielder. 1980. Equal Rights Amendment and Abortion: Separate and Distinct. America 12:314-318.

Baer, Judith. 1991. Women's Rights and the Limits of Constitutional Doctrine. Western Political Quarterly 44:821-852.

Caldeira, Gregory, and John Wright. 1988. Interest Groups and Agenda Setting in the Supreme Court of the United States. American Political Science Review 82:11091127.

Caplan, Lincoln. 1987. The Tenth Justice: The Solicitor General and the Rule of Law. New York: Knopf.

Cole, David. 1984. Strategies of Difference: Litigating for Women's Rights in a Man's World. Law and Inequality 2:33-95.

Epstein, Lee, and C.K. Rowland. 1991. Debunking the Myth of Interest Group Invincibility in the Courts. American Political Science Review 85:205-217.

Epstein, Lee, and Joseph Kobylka. 1992. The Supreme Court and Legal Change-Abortion and the Death Penalty. Chapel Hill: University of North Carolina Press.

Epstein, Lee, and Karen O'Connor. 1988. States and the U.S. Supreme Court: An Examination of Litigation Outcomes. Social Science Quarterly 69:660-674.

Fielder, Maureen. 1984. Bishops' ERA Position Avoids Equality Issue for Abortion Statement. National Catholic Reporter 8:30-32.

George, Tracey, and Lee Epstein. 1991. Women's Rights Litigation in the 1980s: More of the Same? Judicature 74:314-321.

Ginsburg, Ruth Bader. 1988. Remarks on Women Becoming Part of the Constitution. Law and Inequality 2:19-25.

Ginsburg, Ruth Bader, and Barbara Flagg. 1989. Some Reflections on the Feminist Legal Thought of the 1970s. University of Chicago Legal Forum (1989):9-21.

Goldstein, Leslie. 1988. The Constitutional Rights of Women. Madison: University of Wisconsin Press.

Gryski, Gerard, Eleanor Main, and William Dixon. 1986. Models of State High Court Decision Making in Sex Discrimination Cases. Journal of Politics 48:143-155.

Hagle, Timothy. 1992. But Do They Have to See It to Know It? The Supreme Court's Obscenity and Pornography Decisions. Western Political Quarterly 45:1039-1054.

Ignagni, Joseph, and Thomas R. Marshall. 1994. Who Supports Rights? The Supreme Court and Public Opinion. Judicature 78(3):146-151.

Kirp, David, Mark Yudof, and Marlene Strong Franks. 1986. Gender Justice. Chicago: University of Chicago Press.

Mansbridge, Jane. 1986. Why We Lost the ERA. Chicago: University of Chicago Press. Markowitz, Deborah. 1989. In Pursuit of Equality: One Woman's Work to Change the Law. Women's Rights Law Reporter 11:73-97.

Marshall, Thomas R. 1989. Public Opinion and the Supreme Court. Boston: Unwin Hyman.

Mathew, Donald G., and Jane DeHart. 1990. Sex, Gender, and the Politics of the ERA. New York: Oxford University Press. 
Miller, Margaret. 1985. Justice Sandra Day O'Connor: Token or Triumph from a Feminist Perspective. Golden Gate University Law Review 15:493-524.

Minor, Martha. 1987. The Supreme Court 1986 Term, Foreward: Justice Engendered. Harvard Law Review 101:10-45.

Mishler, William, and Reginald Sheehan. 1993. The Supreme Court as a Countermajoritarian Institution? The Impact of Public Opinion on Supreme Court Decisions. American Political Science Review 87:87-101.

O'Connor, Karen. 1980. Women's Organizations' Use of the Courts. Lexington, MA: D.C. Heath.

1988. She Shall Overcome. Human Rights 15:24.

O'Connor, Karen, and Lee Epstein. 1983. Sex and the Supreme Court: An Analysis of Judicial Support for Gender-Based Claims. Social Science Quarterly 64:327-331.

O'Connor, Karen, and Jeffrey Segal. 1990. Justice Sandra Day O'Connor and the Supreme Court's Reaction to Its First Female Member. In Naomi Lynn, ed., Women, Politics and the Constitution. New York: Haworth Press.

Rehnquist, William. 1987. The Supreme Court. New York: William Morrow.

Rhode, Deborah. 1989. Justice and Gender. Cambridge: Harvard University Press.

Rubin, Eva. 1986. The Supreme Court and the American Family. New York: Greenwood Press.

Savage, David. 1992. Turning Right-The Makings of the Rehnquist Supreme Court. New York: John Wiley \& Sons.

Segal, Jeffrey. 1984. Predicting Supreme Court Cases Probabilistically: The Search and Seizure Cases, 1962-1981. American Political Science Review 78:891-900.

Segal, Jeffrey, and Harold Spaeth. 1993. The Supreme Court and the Attitudinal Model. New York: Cambridge University Press.

Sherry, Suzanna. 1986. Civic Virtue and the Feminine Voice in Constitutional Adjudication. Virginia Law Review 72:543-616.

Smith, Tom. 1990. Liberal and Conservative Trends in the United States Since World War II. Public Opinion Quarterly 54:479-507.

Stidman, Ronald, Robert Carp, and C.K. Rowland. 1983. Women's Rights Before the Federal District Courts, 1971-1977. American Politics Quarterly 11:205-218.

Stimson, Jim. 1992. Public Opinion In America-Moods, Cycles, and Swings. Boulder: Westview. 